\title{
Application of Electronic Commerce in the Field of Higher Education
}

\author{
Chang Jinming ${ }^{1, a}$, Niu $\mathrm{Bo}^{2, b}$ \\ ${ }^{1}$ School of Economics and Management, Beijing City University, Beijing, 100083, China \\ ${ }^{2}$ School of Economics and Management, Beijing City University, Beijing, 100083, China \\ acjm0801@163.com, bchiubo@163.com
}

Keywords: electronic commerce higher education domain application

Abstract. The electronic commerce has the bigger development potential in the higher education. In this information time, the progress of higher education method has close correlation with electronic commerce system development. The electronic commerce has provided the brand-new technical method for the higher education, and simultaneously the higher education has provided the profit pattern and the environment for the electronic commerce. This article has analyzed electronic commerce characteristic as well as the application present situation in the higher education domain, and it has studied the question which exists in the application, and further proposed the corresponding solution. The electronic commerce take the future world commerce pattern as a main development direction, and its prospect wouldn't be allowed to suspect. The education is an eternal subject of the development of the human race. Under the condition of knowledge economy, it needs the intelligent guidance of the electronic commerce.

\section{Introduction}

In a narrow sense, e-commerce means some kinds of commercial activities such as advertisement, transaction, payment and service conducted through electronic information technology especially Internet technology, which is electronization, networking and paperless of commercial activities.

Broadly speaking, e-commerce is various of activities based on commercial deal, public business information sharing, online business deal and users' interaction through electronic information technology especially for online technology. In other way, it is activities resulted from e-commerce's management, mode and technology of conduction's permeation into many social activities' areas.

\section{Features of E-Commerce in Higher Education Domain.}

In the higher education, by using basic network, computer hardware and software and other electronic communicating methods to establish e-commerce system, many kinds of needs in business, work, study and life can be met. From the view of business operation mode, it is same as common e-commerce system both of which exchange commodity, service or information by network. But compared with common e-commerce, it has features as following.

(1)Fine Internet Environment

Characterized by intensive knowledge, universities are one of the places with the highest penetration of computer. Most of the universities are equipped with internal LAN (local area network) which connects most of the departments, agencies, dormitories and other places within the campus in order to transfer and share information resources, improve the efficiency and achieve optimization and grouping. Campus websites are held open to service all day long at a rather low cost. Besides, universities boast many advanced laboratories, thus providing a fine environment for students to carry out e-commerce simulation and operation.

(2) Stable Consumer Colony

Universities have stable customer groups such as students and professors. Each year, thousands of new students bring fresh blood to the campus e-commerce. The groups on campus are of high quality and easy to accept something new, especially students at the age group of 18 to 25 who have a strong thirst for knowledge and thus are the main force for conducting e-commerce. 
(3) Secure Payment System

Internet security and payment risk are the two obstacles for the development of e-commerce. Campus network usually links the Internet to firewall system, which ensures the security of network systems. E-commerce payment systems of universities generally employ campus One-Card to finish micro payments, avoiding or reducing the risk of the card number being stolen while paying with credit card or debit card on the internet.

(4) Convenient Delivery and Distribution

Professors and students live in a concentrated area, which enables the delivery service to be precise and timely and greatly reduces the cost. The majority of universities solve the last-mile problem of the traditional e-commerce by allowing poverty-stricken students to take a part-time job while studying at college and at the same time promote the advancement of e-commerce in the field of higher education.

(5) Sound Credit Mechanism

The electronic commerce credit system is not perfect, which hinders badly the development of e-commerce. Electronic commerce credit is mainly depended on personal credit, business credit and social credit. If the supervisory mechanism is unhealthy, there will be all kinds of credit crisis. Under the circumstance of electronic commerce of tertiary education, once it turns up violations, the teachers and register businesses around schools who both are involved in the trade, will be exposed to public. Therefore, they cherish and protect themselves' reputation very much, and foster healthy personal credit and reasonable business credit consciously.

\section{Application Status of Higher Education in the Field of E-Commerce.}

Higher Education of e-commerce serves most teachers, students and staffs via campus network which remains behind relatively. So far, the e-commerce system of oversea colleges has been developed, such as the sound online shopping system, the sound online payment system etc., which provides a great convenience to them. For example, students could use credit or smart card to shop online, to pay tuition and medical fee online, etc., what's more, parents could be able to pay some fee instead of their children. However, it remains some problems, such as most systems do not fully consider the unique campus environment, targeted to be strengthened, and in the secure payment also needs to be further improved. Nevertheless, compared with overseas. The current situation in our country is worst. Because, on the one hand, it is still at an early stage, with many colleges having not carried out yet. On the other hand, most of the colleges that has came into effect have problems too. For instance, only provide online information browsing, online payment has not been achieved, users could pay only through bank transfers or cash. Besides, the services provided is relatively small, which is not convenient in fact. Thus, the construction of the campus e-commerce system needs to be more sound.

\section{Problems in E-Commerce in the Field of Higher Education.}

(1) Lacking of sufficient knowledge of e-commerce of higher education.

First of all, people know little about e-commerce. Due to the influence of the external environment, people overwhelm the network education, and serious profit-oriented thinking, inter-school competition, following the trend of serious, being blind in the absence of sufficient funding for education situation "Pave the Way", making the network hardware construction as the only standard of the implementation of modern education, informational education, the quality of improving education, result in the loss of unrealistic education funding waste.

Secondly, colleges are lack of the theory of education revolution. Many people think that e-commerce is just to update the management equipment campus. However, practice shows that simply to change management methods have been insufficient to cope with the rapid changes in the external environment, in order to successful change must start from educational management innovation. In other words, the most fundamental education information is not a technical issue, but thinking problems, so in the process of information technology in education, do not let technology 
become slaves factors, but should let the technology, "convergence" in people life, teachers and students in fusion.

(2) Lacking of the overall planning, e-commerce in university attaches great important to network device but despises application system under it construction.

At the early stage of e-commerce construction in many universities, lacking of the overall planning, necessary network construction supervisors and the strength in this project can cause many problems such as poor quality of networking, online traffic, bandwidth shortage, poor accessibility, long waiting time, etc. Without considerations about perspective and development direction of networking technology, those universities give priority to the short run, coveting cheat to buy outmoded even obsolete devices. It leads universities harder to expand business at later period and to make overlapping investments or wrong investment.

In addition, being short of e-commerce applications for university, most of those so-called "campus network" in market are the device solutions proposed by some manufacturers basing on advanced hardware, having no complete application system so that it can't serve the education well. Our higher learning institutions were requested to build their own campus net by Ministry of Education. To accomplish it, many universities lack of overall concept and overall planning in the planning stage because of limited financial, being willing to invest hardware devices rather than applications. After the completion of hardware platform, campus network become a general tool for reading online news and e-mailing, especially for some people to trade stocks or chat online, but it doesn't become an advanced tool for teaching, researching and teaching management. It's because of multiple factors such as follow-up funds, concepts, applications, management system and so on. Therefore, the building of campus network doesn't reach its real purpose.

(3) Lacking of interdisciplinary talents who have deep understanding to e-commerce in universities. As an emerging educational form, e-commerce in the field of higher education must has a new cultural concept support and interdisciplinary talents who understand both IT technology and modern educational technology theory and method to take its advantages fully. These talents should come from the faculty in frontline of online education. However, since network and software developers are scarce talents in this industry today, if schools can't afford much salary as social firms, then schools at all levels must have the situation that network application developers are insufficient. Under the influence of traditional education attitude and modern educational technology environment, this kind of talents is scarce. This situation becomes the development bottleneck of e-commerce application in higher education field and restricts the development of university e-commerce.

(4) Lacking of strong supervision.

New living and life way built by network age is affecting the emotion, thought and mind of university students. Internet has a large amount of information, which has high spread speed, interactivity and openness. It's no doubt many people will worry about its negative effect. Network management has become an important issue of university e-commerce management. Now, there are two main problems. First, control on internet contents is insufficient. Some schools' disorder phenomenon on campus network management has led to the uncontrolled actions happening sometimes, such as device damage and bad connection, etc. Second, network security performance is bad. Such as IP address being stolen, exclusive resources being changed into shared resources, invasion and spread of computer virus, master server being hacked, etc. Therefore, building reliable security system has been putting into an important position in university e-commerce construction.

\section{Corresponding solutions.}

(1) Do researches about the building of e-commerce well and make a demonstration project of the development scheme well.

Before building the e-commerce, it's necessary to do some researches and analyze exactly. We can take a department as a unit to do a needs survey of e-commerce, and set targets about the e-commerce on the basis of the survey results and the medium and long term development planning of each college to ensure the advancement, development, feasibility and economy of the development scheme. The 
development scheme of e-commerce takes an important part in the whole campus network, it refers to the layout, construction, bandwidth, total planning, first-stage project scale, security, expandability, technical standard, equipment selection, realizable functions of e-commerce. Therefore, the colleges should study seriously, combine with their actual demands, and consider various elements to revise and perfect in accordance with the technical standard and uniform requirements which are made by the education department. The colleges should also apply for demonstration from the education department and the campus network experts in the units concerned, and form the development scheme of e-commerce which fits the reality of each college on the basis of above-mentioned works.

(2) Set up the secure payment system of e-commerce

The problem which teachers, students and staff care about most is the safety problem. Only if the campus e-commerce ensures the security of online trading can students use e-commerce to pay tuition, accommodation and shopping expenses trustingly. It's necessary to adopt effective strategies and improve the credibility and satisfaction.

(3) According to the needs of teachers, students and staff, provide a superior service

The campus e-commerce system can provide various serves to satisfy the needs about study and life of teachers, students and staff.

(4) Perfect relevant law regulations

Use the law to restraint some Internet behaviors, prevent the Internet cheats and fake commodities.

(5) Strengthen propaganda and education, change traditional ideas

The traditional consumption model is still taking a leading part in the market, it's necessary to change the traditional ideas of teachers, students and staff to accept the e-commerce system, and the project needs incessant propaganda and education.

\section{Conclusions}

At present, almost all of colleges have realized the importance of camps informatization. And most of colleges have established campus network and management system. It benefits the implement of the college e-commerce system. The applications of e-commerce in higher education field can influence the college's teaching management, teaching methods and learning styles directly.

\section{Acknowledgements}

This work was financially supported by the fund project: Beijing City University construction project of off-campus base and experimental teaching demonstration center, the source of Beijng municipal education commission___service regional economic and social development.

\section{References}

[1] Du Jiangping. An analysis of the campus electronic commerce model[J]. Journal of Jiangxi University of Finance and Economics,2005.3.

[2] Wu Qianqian, Wang Yuqi. Problems and solutions in the development of campus e-commerce[J]. Jiangsu business theory,2005.10.

[3] Mou Kai. Some thoughts on the current e-commerce about higher education[J]. Social sciences review,2006.9.

[4] Han Liyan, An Likui, Xu Dianjun. Analysis and research of higher education innovation concept to the informationization development—- the necessity of education electronic commerce[J]. Market modernization,2007.7.

[5] Xu Piwen, Zou Xiaoyu. On the reform of higher education teaching method in the internet era[J]. Journal of national academy of education administration,2014.12. 